\title{
DESIGN
}

\section{DOI https://doi.org/10.30525/978-9934-26-117-6-41}

\section{ФУНКЦІї ГРАФІЧНОЇ ІНТЕРПРЕТАЦІї КОЛИСКОВИХ ПІСЕНЬ}

\author{
Бабкіна Б. I. \\ бакалавр кафедри дизайну та основ архітектури
}

Бабкіна О. I.

студентка III курсу кафедри дизайну та основ архітектури

Інститут архітектури та дизайну

Національного університету «Львівська політехніка»

м. Львів, Украӥна

Дитячу книгу розглядають як органічне поєднання мистецького витвору й засобу формування особистості дитини. Важливу роль у формуванні світогляду маленького читача відіграє не лише текстова інформація, але й ілюстративний матеріал, який дає можливість глибше зрозуміти та емоційно відчути словесний зміст. Своєрідним першоджерелом формування емоційного й когнітивного розвитку дитини $\epsilon$ книжкове видання колискових пісень, яке привертає увагу своєю графічною інтерпретацією мелодійно-текстового змісту.

Книжкові видання колискових пісень призначені для маленького читача, а тому вони повинні мати особливий, оригінальний дизайн, притаманний саме такому жанрові. Оскільки маленька дитина ще не вміє читати та у неї переважає візуальний канал сприйняття, важливо зацікавити іiї насамперед дизайном книги. Стилістика ілюстрацій, кольорова гама, художня інтерпретація образів, місце об'єктів на сторінці колискових видань можуть бути темою для спостереження та обговорення. Тематика колискових пісень характеризується розмаїттям і барвистістю образів. Художнику-ілюстратору потрібно відтворити змістове навантаження колискової пісні, оригінально передаючи зміст художніми засобами, і тим самим привернути увагу дитини, зацікавити iii, залучити до перегляду книги як до гри.

Колискові пісні доступні для дитячого сприйняття. Уже з перших років життя дитини вони мають значний позитивний вплив на процес іiі емоційного, розумового, морального, освітньо-виховного, соціального 
розвитку. Саме тому графічна інтерпретація колискових пісень виконує певні функції.

Різноманітні функції українських колискових пісень та книжкової ілюстрації як засобу візуальної комунікації висвітлюються в дослідженнях О. Марчун, Е. Огар, Н. Сивачук, Ю. Федіної та ін. Дослідники виокремлюють наступні функції: інтерпретаційну, пізнавально-навчальну, виховну, естетичну, доповнювальну (Е. Огар) [4, с. 142]; освітньо-виховну (Ю. Федіна) [5, с. 120-121]; оніричну, апотропеїчну, когнітивну, комунікативно-глосолативну, фрустративну (О. Марчун) [1, с. 101]; практично-побутову, пізнавальну, емоційну, моральноетичну, психотерапевтичну, формування естетичного чуття (Н. Сивачук) [3, с. 49-50]. Також розглядають функції ілюстрації: аргументуючу, сатиричну, символічну, характерологічну та інші.

Беручи до уваги значний вплив колискової пісні та їі графічної інтерпретації на розвиток малюка, виділяємо функції ілюстрації колискових пісень, які, на нашу думку, мають чітке спрямування на емоційно-когнітивне та комунікативно-соціальне формування дитини:

- онірична (функція, яка стимулює дитину до засинання, художнім образом є Сон-Дрімота);

- антифрустративна (функція, яка заспокоює дитину, основними художніми образами ілюстрацій є дитинка в колисці, воркотання гуль і котика, заколисування вітерцем тощо);

- атрактивна (функція, яка спрямована на візуальне сприйняття текстового матеріалу, щоб привернути увагу читача);

- інформаційна (функція, яка розкриває змістову насиченість тексту, щоб ілюстрація сприймалася з текстом як єдине ціле);

- емоційна (функція, яка впливає на емоційний стан дитини, щоб ілюстрації викликали в дитини позитивні емоції: радість, здивування, сміх, захоплення, любов, ніжність тощо);

- естетична (функція, яка впливає на художнє сприйняття тексту, розвиває естетичні смаки дитини);

- когнітивна (функція, яка формує здатність мозку дитини пізнавати, розуміти, сприймати, переробляти інформацію);

- навчально-виховна (функція, яка розвиває розумові здібності дитини, формує їі моральні якості, правила поведінки, етичні норми);

- комунікативно-соціальна (функція, яка формує ознаки соціалізації, комунікації та взаємодії в соціальному середовищі).

Потрібно зазначити, що не обов' язково всі функції мають одночасно застосовуватися в ілюстрації конкретної колискової. Однак, їх розглядають як системний комплекс, як взаємодію та доповнення одна одної. Початковою функцією в колискових вважається заспокійлива i 162 
та, що спонукає до сну. Центральною функцією ілюстрації все ж таки вважають педагогічну, яка включає навчально-виховну, комунікативносоціальну, когнітивну, естетичну. Кожна функція поєднує в собі позитивні компоненти, орієнтуючись на інтерпретацію вербального змісту колискової в контексті традиційного народного світогляду, національно-етнічного кодування.

Наприклад, виховна функція ілюстрації, як зазначає Ю. Федіна, реалізується шляхом показу не завжди зрозумілих з тексту зв'язків між явищами і особами, допомагає визначити власне місце в тих чи інших процесах [5, с. 121]. Через зорове сприйняття в дитини формується емоційне ставлення до персонажів та їх вчинків.

Колискова пісня базується на міфопоетичних уявленнях про світ i це чітко простежується на функціональному рівні графічної інтерпретації вербального змісту. Для ілюстрації колискової пісні притаманний символічний ряд, національний колорит, етнічні мотиви. Графічно розкриваються різні сюжети: міфічні образи, через які передаються почуття матері до дитини, думки про ii долю (наприклад, Сон-Дрімота охороняє спокійний сон немовляти), антропоморфні персонажі тварин і рослин (Котик-Воркотун заколихує маля, Гулі заспокоюють дитинку, билинка, яка є колисочкою для немовляти тощо).

Широке розмаїття мотивів колисанок передає духовне багатство народу, його моральні якості та цінності, педагогічну мудрість тощо. Етнічні мотиви колисанок сприяють входженню дитини до певного етносу, засвоєнню національних звичаїв і традицій. Колискову пісню, як стверджує Н. Сивачук, можна вважати першою енциклопедією українознавства, вона ознайомлює дитину зі світом рідного етносу, його мовою, релігією, історією, культурою, мораллю, звичаєвістю, через неї дитина отримує перші уявлення про народні ідеали, про добро та зло [2, с. 53].Через графічне зображення змісту колискової пісні підсвідомо формується світогляд дитини, вона отримує перші кроки соціальної взаємодії та комунікації.

Отже, колискова пісня є багатофункціональним фольклорним явищем. Кожний елемент вербального тексту і графічної інтерпретації колискової пісні має символічне значення та спрямований на розвиток i виховання дитини, на іï заспокоєння та емоційний стан. Через вербально-візуальний зміст колискової пісні відбувається як біологічне, так і культурно-соціальне пристосування дитини до суспільного життя, що має на меті їі залучення до рідної мови та національних традицій. 


\title{
Література:
}

1. Марчун О. Питання комплексного аналізу українських колискових. Народна творчість та етнологія. 2005. № 2. С. 97-102.

2. Сивачук Н. Виховний потенціал українських народних колискових пісень. Початкова школа. 2006. №1. С. 51- 55.

3. Сивачук Н. П. Український дитячий фольклор : підручник. К. : Деміург, 2003. 288 с.

4. Огар Е. І. Дитяча книга: проблема видавничої підготовки : навч. посіб. Львів : Аз-Арт, 2002. 159 с.

5. Федіна Ю. Освітньо-виховний потенціал ілюстрації дитячої книги. Вісник інституту розвитку дитини. 2014. Вип. 35. С. 119-124.

\section{DOI https://doi.org/10.30525/978-9934-26-117-6-42}

\section{ОСОБЛИВОСТІ ФОРМУВАННЯ ЗОВНІШНЬОГО ІМІДЖУ ЗАКАРПАТСЬКОГО УКРАЇНСЬКОГО ТЕАТРУ ЗА ДОПОМОГОЮ ТЕАТРАЛЬНОГО КОСТЮМУ}

\author{
Зайцева Е. I. \\ заслужений діяч мистецтв Украӥни, \\ викладач кафедри мистеиьких дисциплін \\ Ужггородський інститут культури і мистецттв \\ м. Ужггород, Україна
}

Сьогодні сучасний театр переживає не найкращі часи. Глядача важко зараз зачарувати, потрясти, втримати... Зменшення глядачів на виставах театрів викликає заклопотаність у адміністрації театру та театральної громадськості. Театр потребує адекватних часу стратегій виживання та розвитку, в сучасних формах залучення глядачів як сьогодні, так і в майбутньому, і для цього необхідно проводити роботу 3 формування i зміцнення іміджу театру. Ця робота $є$ як ніколи актуальною. Особливе значення має імідж для відомих театрів України. Один 3 таких Закарпатський академічний обласний український музично-драматичний театр імені братів Юрія-Августина та Свгена Шерегіїв у м. Ужгород.

Для формування свого іміджу Закарпатський український театр в ювілейний рік шукає нові пласти життя, які він знаходить у засобах виразності театрального мистецтва. Не останнє місце у формуванні іміджу театру займає практика використання театрального костюму. 